\title{
Level of acuity, severity and intensity of care of adults and older adults admitted to the Intensive Care Unit
}

\author{
Nível de agudização, gravidade e intensidade do cuidado de adultos \\ e idosos na admissão em Unidade de Terapia Intensiva \\ Nivel de agudización, severidad e intensidad del cuidado de adultos y \\ personas mayores en la admisión en Unidad de Cuidados Intensivos
}

Renata Eloah de Lucena Ferretti-Rebustini ${ }^{1,2}$, Nilmar da Silva Bispo ${ }^{2}$, Winnie da Silva Alves ${ }^{1,2}$, Thiago Negreiro Dias ${ }^{2}$, Cristiane Moretto Santoro ${ }^{1,2}$, Katia Grillo Padilha ${ }^{1,2}$

How to cite this article:

Ferretti-Rebustini REL, Bispo NS, Alves WS, Dias TN, Santoro CM, Padilha KG. Level of acuity, severity and intensity of care of adults and older adults admitted to the Intensive Care Unit. Rev Esc Enferm USP. 2019;53:e03416. DOI: http://dx.doi.org/10.1590/S1980-220X2017051403416

${ }^{1}$ Universidade de São Paulo, Escola de Enfermagem, Departamento de Enfermagem Médico-Cirúrgica, São Paulo, SP, Brazil.

${ }^{2}$ Grupo de Pesquisa em Enfermagem em Unidade de Terapia Intensiva, EEUSP/ CNPq, São Paulo, SP, Brazil.

\begin{abstract}
Objective: To characterize the level of acuity, severity and intensity of care of adults and older adults admitted to Intensive Care Units and to identify the predictors of severity with their respective predictive capacity according to the age group. Method: A retrospective cohort based on the analysis of medical records of individuals admitted to eight adult intensive care units in the city of São Paulo. The clinical characteristics at admission in relation to severity profile and intensity of care were analyzed through association and correlation tests. The predictors were identified by linear regression and the predictive capacity through the ROC curve. Results: Of the 781 cases $(41.1 \%$ from older adults), $56.2 \%$ were males with a mean age of $54.1 \pm 17.3$ years. The burden of the disease, the organic dysfunction and the number of devices were the predictors associated with greater severity among adults and older adults, in which the organic dysfunction had the highest predictive capacity $(80 \%)$ in both groups. Conclusion: Adults and older adults presented a similar profile of severity and intensity of care in admission to the Intensive Care Unit. Organic dysfunction was the factor with the best ability to predict severity in adults and older adults.
\end{abstract}

DESCRIPTORS

Critical Care Nursing; Aged; Adult; Patient Acuity; Intensive Care Units. 


\section{INTRODUCTION}

The demand for Intensive Care Units (ICUs) has grown as the number of people in need of critical care also increases. Several factors contribute to this increase such as population aging and technological advances which favor the occurrence of therapeutic approaches associated with an increased risk of complications ${ }^{(1)}$. An increase of $5.6 \%$ per year in the ICU admission rate among older adults was estimated between 2001 and $2008^{(2)}$, not only showing the increase in occupation, but also the change in profile.

Faced with the epidemiological changes of the population and with the greater access to intensive care beds, and respecting the admission criteria in these units ${ }^{(1)}$, it is essential to understand the profile of patients admitted to the ICU. Although already described in some studies ${ }^{(3-8)}$, this profile is dynamic by definition, insofar as it accompanies population transitions, therefore requiring constant updating. Characterizing the profile of ICU patients aids in creating public health policies and in elaborating actions that can improve the care of critically ill patients, with the objective of reducing morbidity and mortality, disability and the costs related to health care. Understanding who are the patients who need critical care is relevant, since it directly involves screening, clinical and managerial decision-making, and advanced clinical care ${ }^{(9)}$.

Since the ICU is a place intended for caring of patients who present or may present some degree of organic dysfunction $^{(1)}$, it is expected that the severity of these patients is much higher than that observed in patients in the other wards. The higher severity has been previously described as associated with higher ICU mortality ${ }^{(2,8,10)}$.

In addition to the constant need to revisit the epidemiological profile of adults and older adults in the ICU, to the present date no studies have identified specific admission severity predictors for adults and older adults. Adults and older adults have different characteristics ${ }^{(11-12)}$, which should be considered during the care, aiming at patient safety. Understanding which pre-morbid conditions are associated with greater severity may guide clinical practice toward patient recovery, since the outcome of care also depends on factors identified upon admission ${ }^{(6)}$.

Thus, the present study aimed to characterize the level of acuity, severity profile and intensity of care of adults and older adults admitted to ICUs and to identify the predictors of severity with their respective predictive capacity according to the age group.

\section{METHOD}

This is a retrospective cohort study in which the medical records of individuals admitted to several specialized ICUs of a large public hospital in the metropolitan region of São Paulo were analyzed. The specialties of the ICU where the study was conducted were: medical clinic/pneumology; emergency medical clinic; surgical; neurology; trauma; infectious diseases; nephrology and burned patients.

Of the 890 eligible cases (age greater than or equal to 18 years and admission to one of the study ICUs), 781 cases were included and 109 excluded (105 not found and four incomplete medical records). The following variables were extracted from the medical records: gender; age; time interval from illness onset that triggered hospitalization and arrival at the hospital (door); origin/referral; time interval between arrival and admission to the ICU (ICU); type of hospitalization; specialty of the ICU; medical diagnosis at admission; number of comorbidities; personal background; length of hospital stay; survival.

The characterization of the level of acuity was carried out through an analysis of the following variables: disease burden prior to admission (measured by the Charlson Comorbidity Index - CCI); severity on the first day (measured by the Simplified Acute Physiology Score II - SAPS2); organic dysfunction on the first day (measured by the Logistic Organ Dysfunction System - LODS). The intensity of care was characterized according to the variables: number of prescribed drugs; use of sedation, use of vasoactive drugs; use of invasive mechanical ventilation; performing dialysis; number of invasive devices (e.g., probes, drains and catheters) and the existence of pressure lesion upon admission. All variables were analyzed in the first 24 hours of ICU admission.

The data were stratified into two groups for the analyzes: adults (up to 59 years) and older adults ( $\geq 60$ years). The older adults were divided into three subgroups: youngold (60-69 years); old (70-79 years) and oldest old ( $\geq 80$ years). Data were analyzed using descriptive statistics and statistical tests were used. The Student's t-test and ANOVA were used to compare means. The Mann-Whitney test was used to compare medians. Linear regression models were constructed in order to identify which were predictors of severity (as pointed out by the SAPS2) in adults and older adults, assuming severity as a dependent variable. The independent variables that initially composed the model were: gender, door to ICU time, disease burden, organic dysfunction, number of medications, use of sedation, use of vasoactive drugs, use of invasive mechanical ventilation, dialysis, number of invasive devices and presence of pressure lesions. The variables entered the model through the stepwise backward procedure. Only the variables that reached statistical significance in the model $(\mathrm{p} \leq 0.05)$ were maintained in the final regression model.

A ROC analysis (Receiver Operating Characteristic) was performed to verify the predictive capacity of each predictor, and we used the mean SAPS2 score found in the present analysis to classify the state of greater severity. Predictors with good predictive capacity to predict greater severity were considered as those whose area under the curve (AUC) was higher than 0.70. All analyzes were performed using SPSS software (version 22), and the level of significance adopted in two-tailed tests was $\leq 0.05$.

The study was conducted between 2012 and 2017. All procedures were approved by the Local Ethics Committee (Number 447.731/2013) and are in accordance with national regulations for research involving human beings.

\section{RESULTS}

Of the 781 cases included, 439 were males $(56.2 \%)$ and $342(43.8 \%)$ were females. The older adults accounted for 
$41.1 \%$ of the cases $(n=321)$. The mean age of the sample was $54.1 \pm 17.3$ years (18-99 years), being higher among women $(56.4 \pm 17.6$ years $)$ than among men $(52.3 \pm 17.6$ years $)$, and this difference was statistically significant $(\mathrm{p}<0.001)$.

The main conditions that led to ICU admission were trauma $(n=101,12.9 \%)$, cardiovascular $(n=100,12.8 \%)$ and neurological diseases $(n=100,12.8 \%)$. The causes of admission were different among adults and older adults $(\mathrm{p}<0.021)$. Among adults, trauma/external causes were the main cause of admission, while cardiovascular disease were the main cause for older adults. Other causes of admission among adults were neurological and cardiovascular diseases. Among older adults, other conditions were those related to the digestive and neurological system. The admission characteristics of the sample are presented in Table 1. The main causes of admission, according to the related organic system, are presented in Figure 1.

Table 1 - Characteristics of adults and older adults at ICU admission, length of ICU stay and survival - São Paulo, SP, Brazil, 2012-2017.

\begin{tabular}{|c|c|c|c|}
\hline & Adults & Older adults & p-value \\
\hline $\begin{array}{l}\text { Time (days) Disease onset - } \\
\text { door [median (variation)] }\end{array}$ & $1(0-9,125)$ & $2(0-730)$ & $0.167^{*}$ \\
\hline \multicolumn{4}{|l|}{ Origin/Referral [n (\%)] } \\
\hline Emergency Room & $199(30.3)$ & $150(22.9)$ & \multirow{3}{*}{$0.948^{+}$} \\
\hline Operating room & $136(20.7)$ & $79(12.0)$ & \\
\hline Medical Ward & $38(5.8)$ & $14(2.1)$ & \\
\hline $\begin{array}{l}\text { Time (hours) door - ICU } \\
\text { [mean (SD)] }\end{array}$ & $3.0(6.4)$ & $3.45(6.5)$ & $0.444^{* *}$ \\
\hline \multicolumn{4}{|l|}{ Type of hospitalization [n (\%)] } \\
\hline Clinical & $281(36.0)$ & $210(26.9)$ & \multirow{3}{*}{$0.150^{+}$} \\
\hline Elective surgery & $87(11.1)$ & $60(7.7)$ & \\
\hline Emergency surgery & $92(11.8)$ & $51(11.5)$ & \\
\hline \multicolumn{4}{|l|}{ Medical specialty [n (\%)] } \\
\hline Surgical & $76(9.7)$ & $56(7.2)$ & \multirow{8}{*}{$0.048^{+}$} \\
\hline $\begin{array}{l}\text { Clinical Medical/ } \\
\text { Pulmonology }\end{array}$ & $43(5.5)$ & $25(3.2)$ & \\
\hline Emergency Medical Clinic & $109(14.0)$ & $100(12.8)$ & \\
\hline Infectious Diseases & $15(1.9)$ & $13(1.7)$ & \\
\hline Nephrology & $18(2.3)$ & $21(2.7)$ & \\
\hline Neurology & $78(10.0)$ & $41(5.2)$ & \\
\hline Burned & $5(0.6)$ & $2(0.3)$ & \\
\hline Trauma & $116(14.9)$ & $63(8.1)$ & \\
\hline
\end{tabular}

Admissional Medical Diagnosis according to the organic system [n (\%)]

\begin{tabular}{lccc} 
Neurological & $68(8.7)$ & $32(4.1)$ & \\
Respiratory & $29(3.7)$ & $26(3.3)$ & \\
Cardiovascular & $41(5.2)$ & $59(7.6)$ & \\
Digestive & $30(3.8)$ & $40(5.1)$ & \\
Renal & $6(0.8)$ & $6(0.8)$ & \multirow{2}{*}{$0.021^{+}$} \\
Endocrine-metabolic & $12(1.5)$ & $2(0.3)$ & \\
Hemato-infectious & $17(2.2)$ & $21(2.7)$ & \\
Neoplasms & $26(3.3)$ & $23(2.9)$ & \\
Trauma & $87(11.1)$ & $14(1.8)$ & \\
Other & $12(1.5)$ & $4(0.5)$ & \\
\hline Length of stay [mean (SD)] & $7.1(11.1)$ & $6.7(8.5)$ & $0.583^{* *}$ \\
\hline Survival [n(\%)] & $381(48.8)$ & $226(28.9)$ & $0.000^{+}$ \\
\hline
\end{tabular}

* Mann-Whitney test; ${ }^{* *}$ Student's T-test; ${ }^{\dagger}$ Fisher's Exact Test.

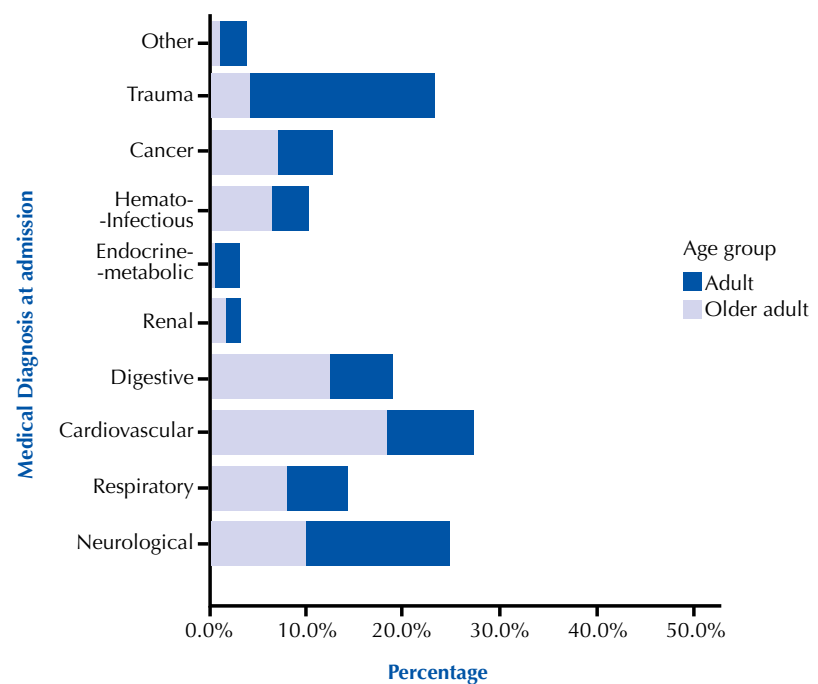

Figure 1 - Distribution of individuals according to the Admission Medical Diagnosis according to the organic systems, in each age group - São Paulo, SP, Brazil, 2012-2016.

The level of acuity and the intensity of care required for adults and older adults admitted to the ICU are described in Table 2. The mean for the severity of the sample, as measured by SAPS2, was $30.5 \pm 15.4$ points. There was no statistically significant difference between the admission severity among the groups.

Table 2 - Level of acuity and intensity of care required in the admission of adults and older adults in the ICU - São Paulo, SP, Brazil, 2012-2017.

\begin{tabular}{lccc}
\hline & Adults & Older adults & p-value \\
\hline $\begin{array}{l}\text { Level of Acuity } \\
\quad \begin{array}{l}\text { Disease burden - CCl } \\
\text { [mean (SD)] }\end{array}\end{array}$ & $1.7(1.9)$ & $1.8(1.9)$ & $0.907^{*}$ \\
$\begin{array}{l}\text { Severity - SAPS2 [mean } \\
\text { (SD)] }\end{array}$ & $30.5(14.7)$ & $30.5(15.3)$ & $0.951^{*}$ \\
$\begin{array}{l}\text { Organic dysfunction - } \\
\text { LODS [mean (SD)] }\end{array}$ & $4.8(3.7)$ & $4.7(4.1)$ & $0.859^{*}$ \\
\hline $\begin{array}{l}\text { Intensity of Care } \\
\text { Number of medications }\end{array}$ & $10.9(5.6)$ & $10.9(5.4)$ & $0.966^{*}$ \\
$\quad$ [mean (SD)] & $142(21.6)$ & $77(11.7)$ & $0.077^{+}$ \\
$\quad$ Sedation [n(\%)] & $4.0(2.8)$ & $3.9(2.6)$ & $0.727^{*}$ \\
$\begin{array}{l}\text { Number of devices [mean } \\
\text { (SD)] }\end{array}$ & $141(21.5)$ & $89(13.6)$ & $0.676^{+}$ \\
$\begin{array}{l}\text { VAD [n(\%)] } \\
\text { MV [n(\%)] }\end{array}$ & $166(27.6)$ & $95(15.8)$ & $0.078^{+}$ \\
$\begin{array}{l}\text { Dialysis [n(\%)] } \\
\text { Pressure Lesions [n(\%)] }\end{array}$ & $150(28.4)$ & $94(17.8)$ & $0.593^{+}$ \\
\hline
\end{tabular}

SD - Standard Deviation; CCI - Charlson Comorbidity Index; SAPS2 Simplified Acute Physiology Score II; LODS - Logistic Organ Dysfunction System; VAD - vasoactive drugs; MV - mechanical ventilation;

* Student's T-test; ${ }^{\dagger}$ Fisher's Exact Test.

When comparing clinical admission characteristics among the three subgroups of older adults (young-old, old and oldest old), no statistically significant difference was observed, except for the mean age in each subgroup, the higher frequency of men among young-old and the door to ICU time, which was lower among oldest old (Table 3).

The independent predictors of severity in each age group and their predictive abilities are presented in Table 4. 
Table 3 - Clinical admission characteristics between young-old, old and oldest-old adults, in the ICU - São Paulo, SP, Brazil, $2012-2017$.

\begin{tabular}{|c|c|c|c|c|}
\hline & $\begin{array}{c}\text { Young-old } \\
158(49.2 \%)\end{array}$ & $\begin{array}{c}\text { Old } \\
109(34.0 \%)\end{array}$ & $\begin{array}{l}\text { Oldest Old } \\
54(16.8 \%)\end{array}$ & p-value \\
\hline Gender [Males [n(\%)] & $97(30.2)$ & $53(16.5)$ & $20(6.2)$ & $0.004^{+}$ \\
\hline Age [mean (SD)] & $64.6(2.6)$ & $73.9(2.9)$ & $84.8(4.1)$ & $0.000^{*}$ \\
\hline Time (days) disease onset - door [median (variation)] & $2.0(0-730)$ & $3.5(0-180)$ & $2.0(0-545)$ & $0.374^{\#}$ \\
\hline Time (hours) door to ICU [mean (SD)] & $4.5(7.8)$ & $2.8(5.0)$ & $1.4(2.4)$ & $0.021 *$ \\
\hline \multicolumn{5}{|l|}{ Level of Acuity } \\
\hline Disease burden - CCI [mean (SD)] & $1.7(1.8)$ & $1.7(1.6)$ & $1.2(1.1)$ & $0.892^{*}$ \\
\hline Severity - SAPS2 [mean (SD)] & $29.1(14.5)$ & $31.2(17.9)$ & $28.3(15.3)$ & $0.927^{*}$ \\
\hline Organic dysfunction - LODS [mean (SD)] & $4.6(4.1)$ & $4.5(4.0)$ & $4.2(3.9)$ & $0.468^{*}$ \\
\hline \multicolumn{5}{|l|}{ Intensity of Care } \\
\hline Number of medications [mean (SD)] & $11.9(5.2)$ & $11.5(5.8)$ & $9.4(4.5)$ & $0.221^{*}$ \\
\hline Sedation $[\mathrm{n}(\%)]$ & 41 (15.6) & $25(9.5)$ & $11(4.2)$ & $0.868^{+}$ \\
\hline Number of devices [mean (SD)] & $4.0(2.7)$ & $3.8(2.6)$ & $3.9(2.4)$ & $0.867^{+}$ \\
\hline $\operatorname{VAD}[\mathrm{n}(\%)]$ & $44(16.8)$ & $29(11.1)$ & $16(6.1)$ & $0.835^{+}$ \\
\hline $\mathrm{MV}[\mathrm{n}(\%)]$ & $53(22.2)$ & $30(12.6)$ & $9(3.8)$ & $0.143^{+}$ \\
\hline Dialysis [n(\%)] & $13(5.0)$ & $07(2.7)$ & - & $0.095^{+}$ \\
\hline Pressure Lesions [n(\%)] & $52(24.6)$ & $29(13.7)$ & $13(6.2)$ & $0.286^{+}$ \\
\hline Length of stay [mean (SD)] & $5.6(8.3)$ & $7.3(8.3)$ & $7.0(8.3)$ & $0.841^{*}$ \\
\hline Survival [n (\%)] & $113(35.2)$ & 76 (23.7) & 37 (11.5) & $0.894^{+}$ \\
\hline
\end{tabular}

SD - Standard Deviation; CCI - Charlson Comorbidity Index; SAPS2 - Simplified Acute Physiology Score II; LODS - Logistic Organ Dysfunction System; VAD - vasoactive drugs; MV - mechanical ventilation; * Student's T-test; ${ }^{\dagger}$ Fisher's Exact Test; ${ }^{*}$ Mann-Whitney test.

Table 4 - Independent predictors of admission severity assessed by SAPS2 and respective predictive capacity in adults and older adults in the ICU - São Paulo, SP, Brazil, 2012-2017.

\begin{tabular}{|c|c|c|c|c|c|c|c|}
\hline Model & & $\mathbf{R}^{2}$ & B & p-value & $95 \% \mathrm{Cl}$ & AUC & p-value \\
\hline \multirow{3}{*}{ Adults } & Disease burden $(\mathrm{CCl})$ & & 1.37 & 0.000 & $0.89-1.86$ & 0.601 & 0.001 \\
\hline & Number of devices & 0.611 & -0.69 & 0.000 & $-1.02--0.36$ & 0.456 & 0.134 \\
\hline & Organic dysfunction (LODS) & & 2.68 & 0.000 & $2.44-2.92$ & 0.862 & 0.000 \\
\hline \multirow{3}{*}{ Older adults } & Disease burden $(\mathrm{CCl})$ & & 1.45 & 0.000 & $0.91-2.00$ & 0.570 & 0.056 \\
\hline & Number of devices & 0.673 & -0.76 & 0.000 & $-1.16--0.35$ & 0.441 & 0.108 \\
\hline & Organic dysfunction (LODS) & & 2.87 & 0.000 & $2.60-3.14$ & 0.875 & 0.000 \\
\hline
\end{tabular}

Dependent variable: severity measured by SAPS2 (Simplified Acute Physiology Score II); CCI - Charlson Comorbidity Index; LODS - Logistic

Organ Dysfunction System; AUC - Area under the curve.

Disease burden, organic dysfunction and number of devices were the independent predictors associated with greater severity in both groups. The same severity predictors were observed among adults and older adults, highlighting a slightly higher severity score in the older adults group. Thus, increased disease burden and organic dysfunction at admission increase the severity measured by SAPS2 (1.37 points and 2.60 points, respectively, among adults and 1.45 points and 2.87 points, respectively, among older adults). The less assistance devices installed in the patient at admission, the greater the severity; the SAPS2 score decreases by 0.69 points among adults and 0.76 points among older adults for each device installed upon admission. The severity prediction model (combining disease burden, organic dysfunction and number of devices) explains $61.1 \%$ of the phenomenon among adults and $67.3 \%$ among older adults.

Regarding the predictive capacity of each predictor, it was observed that organic dysfunction presented predictive capacity superior to $80 \%$ in both groups. Although the disease burden showed statistically significant predictive capacity, the area under the curve was not as good. It was observed that the number of devices alone does not give good predictive capacity.

\section{DISCUSSION}

The results demonstrated that organic dysfunction and disease burden on admission are independent predictors of admission severity, with organic dysfunction being the predictor with the best ability to predict admission severity, both in adults and older adults. In turn, a higher number of devices seems to be associated with a reduction in severity.

It has previously been shown that some isolated admission characteristics such as severity are related to higher mortality ${ }^{(13)}$. Identifying factors associated with greater severity in the ICU is fundamental for care practice, since 
this implies in a higher risk of death and other negative outcomes in the ICU. Mortality is expected to be higher in severe patients, notably among older adults ${ }^{(14)}$. Implementing interventions aimed at reducing severity depends on early identification of the associated factors. Since organic dysfunction and disease burden are two factors associated with greater severity, they should be systematically evaluated and established as the target of interdisciplinary interventions.

In fact, intensive care patients are expected to be more severe, and it is easy to understand that this severity may be due to increased organ involvement as a consequence of the disease or any other condition. When considering the admission criteria in $\mathrm{ICU}^{(1)}$, it is expected the existence of some degree of organic dysfunction upon admission. Although it is expected, establishing this predictive association was not previously described, and therefore this limits the comparison of the results found in the present study. However, it has been shown that organic dysfunction predicts severity in approximately $87 \%$, in addition to being a factor independently associated with greater severity. This means that greater organic dysfunction predicts severity $87 \%$ of the time. It can therefore be inferred that part of the severity is explained by the organic dysfunction that the patient presents and not by the health care and life support devices commonly used in ICUs.

In turn, the disease burden is also an important factor in the patient's admission assessment. While organic dysfunction upon admission provides information about organic impairment, which may be due to an acute condition, the disease burden may be an indicator of the individual's organic reserve. Due to the interaction of several comorbidities, the disease burden may not only be associated with greater severity, but also impose greater difficulty in patient recovery, especially for older adults, thus it can represent a predictor of complications and unfavorable outcomes ${ }^{(15)}$. The disease burden, measured herein by the CCI, should be considered when admitting ICU patients because of its relevant impact on the survival of critical patients ${ }^{(16)}$. Individuals with higher disease burdens present longer hospitalization time ${ }^{(17)}$ and greater chance of in-hospital mortality ${ }^{(9,18)}$.

Thus, it can be understood that admission severity is associated with organic dysfunction presented by an individual with higher disease burden and who may benefit from complex interventions implemented by an interdisciplinary team.

Another factor associated to severity was the number of health care devices, but in an inversely proportional relation since it was observed that the increase in their number was related to the severity reduction. No studies that analyzed this association were found. We would initially expect a different relationship in which the greater number of devices were associated with greater severity, since severely ill individuals need many devices for their treatment. On the other hand, the admission requirements of the study must be considered, in which severity was measured at admission. Individuals with the highest number of devices at admission were possibly those who had already entered the ICU with their treatment started and with severity status already controlled or stabilized. In any case, this association deserves to be further investigated before claiming that the greater number of devices decreases severity. For the time being, it is understood that there is an association.

There was no significant difference between admission severity presented by adults in relation to older adults. In addition, the admission severity was not as high in the sample as a whole. A recent study which examined 19,510 ICU admissions (45.7\% of older adults) between 2001 and 2008 showed that patients' severity at admission decreased over the years ${ }^{(2)}$. Greater access to ICU beds may have interfered in this reduction, considering that the greater availability of beds implies the admission of individuals with lower severity.

Although there was no difference in severity between adults and older adults, there were some differences in the epidemiological profile between the groups. The adults were mostly men, admitted to a specialized trauma ICU due to traumatic conditions or external causes. Although the level of acuity was similar to that observed among older adults, the intensity of care provided was higher among adults, who presented a higher frequency of sedation, use of vasoactive drugs, use of mechanical ventilation and pressure injury.

In turn, the older adults (besides representing almost half of the sample) had a greater frequency of women increasing as their ages advanced, and were more admitted into the emergency medical clinic ICU for treatment of cardiovascular diseases. Although they presented a level of acuity and severity very similar to that of adults, the intensity of care given to older adults was lower. The older adults had a lower frequency of sedation, vasoactive drugs, mechanical ventilation and pressure injury compared to adults. Moreover, the intensity of care in the subgroup of older adults was higher among younger older adults in relation to medication number, frequency of sedation, use of vasoactive drugs, use of mechanical ventilation and pressure injury.

Similar results were obtained in a retrospective study of 1,129 critically ill patients over 80 years old admitted to the $\mathrm{ICU}^{(19)}$. The majority of patients were females $(612$ patients, 55\%) and were admitted for treatment of clinical conditions (772 patients, 68\%). Cardiovascular diseases were the second most frequent cause of hospitalization (185 patients, $16 \%)$. The most commonly received therapeutic support was mechanical ventilation ( $17 \%$ of the patients), and $9 \%$ of the patients received vasoactive drugs ${ }^{(19)}$. Inversely, another national study ${ }^{(3)}$ found that the intensity of care required by older adult patients was much higher than that reported in the present study. Of the 189 patients, almost all of whom were older adults, $50.8 \%$ were given vasoactive drugs and $56.6 \%$ underwent invasive mechanical ventilation. Mechanical ventilation is associated with higher mortality, especially in individuals over 75 years of age ${ }^{(20)}$.

Although several of these differences between groups were observed from analyzing the trends and distributions found, most of them were not statistically significant. Thus, it cannot be said that older adults actually received less aggressive treatment on the first day of ICU admission. In addition to the results related to the level of acuity and intensity of care not being statistically significant, this study did not 
evaluate the suitability of the therapy. Other studies with larger samples are necessary to better explore the trends found which were not confirmed in this study.

The length of hospital stay was similar to that reported in a recent study ${ }^{(21)}$. Comparing the means of hospitalization time in relation to the age group, it was observed that they were very similar and with no statistically significant difference.

Length of hospitalization is an important indicator, since it has been shown that the longer the ICU stay, the greater the chance of adverse events occurring that compromise patient safety ${ }^{(22)}$. Older adults are individuals with a high propensity to suffer adverse events in the hospital environment $^{(22)}$, however, their survival was lower than the survival of adults. An earlier study showed that the mortality of old and oldest-old adults was greater than that of adults ${ }^{(12)}$. It has been reported that age is an independent predictor of ICU mortality. Octogenarians (80-year-old individuals) have a 1.63 times greater chance of in-hospital death, and this odds ratio increases to 2.64 for nonagenarians ( 90 -year-old individuals ${ }^{(23)}$. However, a recent study did not confirm this association among nonagenarians ${ }^{(24)}$.

An interesting finding was a slightly higher door to ICU time among older adults, especially in the subgroup of young-old. It was found that older adults tended to take a little longer to be admitted to the ICU than adults upon arrival at the hospital. This may be clinically justified by the longer time spent confirming the diagnosis among older adults, since atypical clinical presentation may make diagnosis difficult. It has been described ${ }^{(11)}$ that older adults present atypical clinical presentation which demands more from the health professional in terms of clinical reasoning. On the other hand, the young-old had a longer door to ICU time than oldest-old adults.

It is a fact that population aging (considered a worldwide phenomenon) has increased the number of older adults in intensive care ${ }^{(2,11,25-28)}$. The results showed that almost half of the sample consisted of older adults, which is in agreement with other studies that found a similar frequency in the proportion of older adults in the $\operatorname{ICU}^{(2,12,19,25-28)}$. It is expected that this frequency will continue to increase as the number of older adults increases in the different populations.

The various comparisons made in this study between the groups were those based on sociodemographic and clinical indicators (based on severity classification systems, such as the CCI, SAPS2 and LODS), traditionally used in studies with critical patients for evaluating acute physiological disorders and comorbidities that are present at the time of admission. These indicators have shown that the groups are similar in relation to the profile of severity and organic dysfunction.

Nevertheless, it cannot be taken for granted that there are no differences between adults and older adults in the ICU. Several important indicators for profile characterization in older adults were not evaluated. As this was a retrospective cohort, it was not possible to analyze indicators of extreme relevance in aging, such as the cognitive profile of individuals and the occurrence of delirium ${ }^{(28)}$, their functional capacity, in addition to their state of frailty ${ }^{(29)}$, a more recently addressed concept that is becoming increasingly used to provide more accurate prognostic information and to identify a vulnerable population, with increased risk of adverse events, morbidity and mortality ${ }^{(29-30)}$. No records of these indicators were found in the analyzed medical charts, preventing a data analysis with greater geriatric/gerontological focus, which can be considered the main limitation of this study; the non-contemplation of the gerontological indicators in the analyzes. Future studies can be designed trying to explore such aspects. Until then, the matter cannot be considered resolved.

In any case, it is a fact that health professionals should be aware of the repercussions that the aging of the population imposes on intensive care units in order to implement individualized care that respects the specificities of this age group.

There must be an investment in continuing education programs to ensure that the nursing team is equipped to handle care of older adult patients, protecting the aspects of senescence and senility, which will guide the nursing process to achieve the best health outcomes, minimize events that compromise patient safety and reduce morbidity and mortality.

\section{CONCLUSION}

Adults and older adults presented a similar profile of severity and intensity of care at ICU admission. The predictors of admission severity in adults and older adults in the ICU are organic dysfunction and disease burden. A greater number of devices is associated with lower severity. On the other hand, organic dysfunction was the predictor with the best predictive capacity in both age groups. Studies that analyze the profile of older adults, safeguarding the specificities of aging and which analyze relevant gerontological indicators are important.

\section{RESUMO}

Objetivo: Caracterizar o nível de agudização, a gravidade e a intensidade do cuidado de adultos e idosos admitidos em Unidades de Terapia Intensiva e identificar os preditores de gravidade com sua respectiva capacidade preditiva de acordo com o grupo etário. Método: Coorte retrospectiva, com base na análise de prontuários de indivíduos admitidos em oito unidades de terapia intensiva adulto da cidade de São Paulo. Foram analisadas as características clínicas admissionais em relação ao perfil de gravidade e a intensidade do cuidado por meio de testes de associação e correlação. Os preditores foram identificados por regressão linear, e a capacidade preditiva, por meio da curva ROC. Resultados: Dos 781 casos (41,1\% de idosos), 56,2\% eram homens com idade média de 54,1 $\pm 17,3$ anos. A carga de doença, a disfunção orgânica e o número de dispositivos foram os preditores associados à maior gravidade entre adultos e idosos, sendo a disfunção orgânica aquele com maior capacidade preditiva (80\%) em ambos os grupos. Conclusão: Adultos e idosos apresentaram perfil semelhante de gravidade e intensidade do cuidado na admissão na Unidade de Terapia Intensiva. A disfunção orgânica foi o fator com melhor capacidade para predizer gravidade, em adultos e idosos.

\section{DESCRITORES}

Enfermagem de Cuidados Críticos; Idoso; Adulto; Gravidade do Paciente; Unidades de Terapia Intensiva. 
RESUMEN

Objetivo: Caracterizar el nivel de agudización, la severidad y la intensidad del cuidado de adultos y personas mayores ingresados en Unidades de Cuidados Intensivos e identificar los predictores de severidad con su respectiva capacidad predictiva de acuerdo con el rango de edad. Método: Cohorte retrospectiva, con base en el análisis de fichas de individuos admitidos en ocho unidades de cuidados intensivos de la ciudad de São Paulo. Se analizaron las características clínicas de admisión con relación al perfil de severidad y la intensidad del cuidado mediante pruebas de asociación y correlación. Los predictores fueron identificados por regresión lineal, y la capacidad predictiva, mediante la curva ROC. Resultados: De los 781 casos (41,1\% de ancianos), el 56,2\% eran hombres con edad media de 54,1 $\pm 17,3$ años. La carga de la enfermedad y la disfunción orgánica de dispositivos fueron los predictores asociados con la mayor severidad entre adultos y ancianos, siendo la disfunción orgánica aquel con mayor capacidad predictiva (80\%) en ambos grupos. Conclusión: Adultos y personas mayores presentaron perfil semejante de severidad e intensidad del cuidado en la admisión en la Unidad de Cuidados Intensivos. La disfunción orgánica fue el factor con mejor capacidad para predecir la severidad, en adultos y ancianos.

\section{DESCRIPTORES}

Enfermería de Cuidados Críticos; Anciano; Adulto; Gravedad del Paciente; Unidades de Cuidados Intensivos.

\section{REFERENCES}

1. Fullerton JN, Perkins GD. Who to admit to intensive care? Clin Med. 2011; 11(6):601-4.

2. Fuchs L, Novack V, McLennan S, Anthony Celi L, Baumfeld Y, Park S, et al. Trends in severity of illness on ICU admission and mortality among the elderly. PLoS One. 2014;9(4): e93234. DOI: https://dx.doi.org/10.1371\%2Fjournal.pone.0093234

3. Mares C, Biondi RS, Sotero S, Lima AA, Almeida KJQ AF, Amorim FF. Perfil epidemiológico e preditores de mortalidade de uma unidade de terapia intensiva geral de hospital público do Distrito Federal. Comun Ciênc Saúde [Internet]. 2015 [citado 2017 nov. 22];26(12):9-19. Disponível em: http://bvsms.saude.gov.br/bvs/periodicos/ccs_artigos/2015_perfil_epidemiologico.pdf

4. França CDM, Albuquerque PR SA. Perfil epidemiológico da unidade de terapia intensiva de um hospital de reabilitação. InterScientia. 2013;1(2):72-82

5. Schein LEC, Cesar JA. Perfil de idosos admitidos em unidades de terapia intensiva gerais em Rio Grande, RS: resultados de um estudo de demanda. Rev Bras Epidemiol. 2010;13(2):289-301. DOI: http://dx.doi.org/10.1590/S1415-790X2010000200011

6. Bezerra GKA. Unidade de Terapia Intensiva: perfil das admissões: Hospital Regional de Guarabira, Paraíba, Brasil. Rev Bras Ci Saúde. 2012;16(4):491-6.

7. Silva DV, Ximenes GC, Silva Junior JM, Ísola AM, Rezende E. Perfil epidemiológico e fatores de risco para mortalidade em pacientes idosos com disfunção respiratória. Rev Bras Ter Intensiva. 2009;21(3):262-8.

8. Freitas ERFS. Profile and severity of the patients of intensive care units: prospective application of the APACHE II Index. Rev Latino Am Enfermagem. 2010;18(3):317-23. DOI: http://dx.doi.org/10.1590/S0104-11692010000300004

9. Bagshaw SM, Webb SAR, Delaney A, George C, Pilcher D, Hart GK, et al. Very old patients admitted to intensive care in Australia and New Zealand: a multi-centre cohort analysis. Crit Care. 2009;13(2):R45. DOI: http://dx.doi.org/10.1186/cc7768

10. Hissa PNG, Hissa MRN, Araújo PSR. Análise comparativa entre dois escores na previsão de mortalidade em unidade terapia intensiva. Rev Bras Clín Méd. 2013;11(1):21-6.

11. Ferretti-Rebustini REL, Nogueira LS, Silva RCG, Poveda VB, Machado SP, Oliveira EM, et al. Aging as a predictor of nursing workload in intensive care unit: results from a Brazilian sample. Rev Esc Enferm USP. 2017;51:e03216. DOI: http://dx.doi.org/10.1590/s1980$220 \times 2016237503216$

12. Oliveira VCR, Nogueira LS, Andolhe R, Padilha KG, Sousa RMC. Clinical evolution of adult, elderly and very elderly patients admitted in Intensive Care Units. Rev Latino Am Enfermagem. 2011;19(6):1344-51. DOI: http://dx.doi.org/10.1590/S0104-11692011000600010

13. Ho KM, Williams TA, Harahsheh Y, Higgins LT. Using patient admission characteristics alone to predict mortality of critically ill patients: a comparison of 3 prognostic scores. J Crit Care. 2016;31(1):21-5. DOI: http://dx.doi.org/10.1016/j.jcrc.2015.10.019

14. Alves GC, da Silva Júnior GB, Lima RSA, Sobral JB, Mota RMS, Abreu KLS, et al. Fatores de risco para óbito em pacientes idosos gravemente enfermos. Rev Bras Ter Intensiva. 2010;22(2):138-43. DOI: http://dx.doi.org/10.1590/S0103-507X2010000200007

15. Martins M. Uso de medidas de comorbidades para predição de risco de óbito em pacientes brasileiros hospitalizados. Rev Saúde Pública. 2010;44(3):448-56. DOI: http://dx.doi.org/10.1590/S0034-89102010005000003

16. Docking RI, Mackay A, Williams C, Lewsey J, Kinsella J, Booth MG. Comorbidity and intensive care outcome: a multivariable analysis. J Intensive Care Soc. 2014; 15(3):205-12. DOI: https://doi.org/10.1177/175114371401500306

17. O'Sullivan K, Martensson J, Robbins R, Farley KJ, Johnson D, Jones D. Epidemiology of long-stay patients in a university teaching hospital. Intern Med J. 2017;47(5):513-21. DOI: https://doi.org/10.1111/imj.13379

18. Quan H, Li B, Couris CM, Fushimi K, Graham P, Hider P, et al. Updating and validating the charlson comorbidity index and score for risk adjustment in hospital discharge abstracts using data from 6 countries. Am J Epidemiol. 2011;173(6):676-82. DOI: https://doi.org/10.1093/ aje/kwq433

19. Zampieri FG, Colombari F. The impact of performance status and comorbidities on the short-term prognosis of very elderly patients admitted to the ICU. BMC Anesthesiol. 2014;14:59. DOI: https://doi.org/10.1186/1471-2253-14-59

20. Añon JM, Gómez-Tello V, González-Higueras E, Córcoles V, Quintana M, García de Lorenzo A, et al. Prognosis of elderly patients subjected to mechanical ventilation in the ICU. Med Intensiva. 2013;37(3):149-55. DOI: http://doi.org/10.1016/j.medin.2012.03.014

21. Sagy I, Fuchs L, Mizrakli Y, Codish S, Politi L, Fink L, Novack V. Characteristics and outcomes of critically-ill medical patients admitted to a tertiary medical center with restricted ICU bed capacity. J Crit Care. 2018;43:281-7. DOI: https://doi.org/10.1016/j.jcrc.2017.09.177 
22. Toffoletto MC, Barbosa RL, Andolhe R, Oliveira EM, Ducci AJ, Padilha KG. Factors associated with the occurrence of adverse events in critical elderly patients. Rev Bras Enferm [Internet]. 2016;69(6):977-83. DOI: http://dx.doi.org/10.1590/0034-7167-2016-0199

23. Ball IM, Bagshaw SM, Burns KE, Cook DJ, Day AG, Dodek PM, et al. A clinical prediction tool for hospital mortality in critically ill elderly patients. J Crit Care. 2016;35:206-12. DOI: http://doi.org/10.1016/j.jcrc.2016.05.026.

24. Le Borgne P, Maestraggi Q, Couraud S, Lefebvre F, Herbrecht J-E, Boivin A, et al. Critically ill elderly patients ( $\geq 90$ years): clinical characteristics, outcome and financial implications. PLoS One. 2018;13(6):e0198360. DOI: https://doi.org/10.1371/journal.pone.0198360

25. Walker M, Spivak M, Sebastian M. The impact of aging physiology in critical care. Crit Care Nurs Clin North Am. 2014;26(1):7-14. DOI:http://dx.doi.org/10.1016/j.ccell.2013.09.005

26. Maillet JM, Guérot E, Novara A, Le Guen J, Lahjibi-Paulet H, Kac G, et al. Comparison of intensive-care-unit-acquired infections and their outcomes among patients over and under 80 years of age. J Hosp Infect. 2014;87(3):152-8. DOI: http://dx.doi.org/10.1016/j. jhin.2014.03.011

27. Bell L. The epidemiology of acute and critical illness in older adults. Crit Care Nurs Clin North Am. 2014;26(1):1-5. DOI: http://dx.doi. org/10.1016/j.ccell.2013.10.001

28. Amba KT. Delirium in the elderly adult in critical care. Crit Care Nurs Clin North Am. 2014;26(1):139-45. DOI: http://dx.doi.org/10.1016/j. ccell.2013.10.008

29. Le Maguet P, Roquilly A, Lasocki S, Asehnoune K, Carise E, Saint Martin M, et al. Prevalence and impact of frailty on mortality in elderly ICU patients: a prospective, multicenter, observational study. Intensive Care Med. 2014;40(5):674-82. DOI: https://doi.org/10.1007/s00134014-3253-4

30. Bagshaw SM, Stelfox HT, McDermid RC, Rolfson DB, Tsuyuki RT, Baig N, et al. Association between frailty and short- and long-term outcomes among critically ill patients: a multicentre prospective cohort study. CMAJ. 2014;186(2):E95-102. DOI: https://doi.org/10.1503/ cmaj.130639

Financial support

Coordenação de Aperfeiçoamento de Pessoal de Nível Superior (CAPES). Fundação de Amparo à Pesquisa de Estado de São Paulo (FAPESP). Conselho Nacional de Desenvolvimento Científico e Tecnológico (CNPq) and the Fundación Mapfre. 